\title{
PROFITABILITY OF BROILER PRODUCTION IN CROSS RIVER STATE, NIGERIA
}

ETTAH, OTU I., IGIRI, JULIANA A. AND IHEJIAMAIZU, VICTOR C.

(Received 2 June, 2021; Revision Accepted 29 July, 2021)

\begin{abstract}
The study was carried out to determine profitability of broiler production in Cross River State, Nigeria. A three stage multi sampling technique was adopted in the selection of 180 respondents. Data collected were analysed using descriptive statistics such as frequency, mean, ranking and percentages, as well as budgeting techniques tools such as net farm income (NFI), return to naira invested (RNI), gross and operating ratios (GR and OR) respectively. Result of analysis showed that socio-economic attributes of broiler farmers - age, sex, marital status, education, experience, business size and training studied influenced on broiler production in the area. Furthermore, the study revealed that broiler production is a profitable venture in the area. This is arising from the difference between a total revenue of N704, 000 and total cost of N419, 153 respectively, representing a net profit of N284, 646.6 or $67.90 \%$ of the total amount of money invested, within a production season of eight weeks. The return per naira invested ratio was 1.64 , this meant that for every naira invested, N1.64 profit was made by the broiler farmer, this further indicated that the business is profitable. The gross ratio, which measured the overall financial success of the business recorded 0.61 . However, cost of feeds, lack of extension services, financial constraints, cost of day old chick's medication among others are the constraints affecting effective broiler production in the area. Based on the findings of this study, the following are recommended: regular extension training on broiler production should be carried out by the relevant government agencies, feeds should be subsidized and made easily available by government, production of day old chicks should be subsidized by government to cushion the effect of their high cost and livestock farmers should be encouraged to invest on the poultry subsector for it profitability.
\end{abstract}

KEYWORDS: broiler, profitability, poultry, production, ratios

\section{INTRODUCTION}

Broilers are simply chicken raised for meat and it production is the process of rearing broiler birds for meat, a key measure of performance being the feed conversion ratio (FCR). According to Mgbakor and Nzeadachie (2013) broiler production of the poultry enterprise has great potentials for increasing protein supply in Nigeria, because of their fast growth rates and prolificacy, which can be adapted under a wide range of marginal climatic conditions and can generally be combined conveniently with other farm enterprises and/or occupation, with mutual benefits to the farmer.
The importance of broiler is further noted by Ezeano and Ohaemesi (2020) to include: offers high productiveness, fast growth rate, short generation interval and unparalleled competence in nutrient transformation to high quality animal protein. In spite of these laudable attributes of the industry, it is still faced with the following according to Ike and Ugwumba (2011): poor reproductive performance, poor growth rates, diseases, mortality, predation and low level of literacy among farmers, as well as poor market for the product in small holder broiler production.

The Nigerian's broiler resources consist of about $104,247,960$ birds (NBS, 2020), representing about

Ettah, Otu I., Department of Agricultural Economics, Faculty of Agriculture, Forestry and Wildlife Resources Management, University of Calabar, PMB 1115 Calabar, Nigeria.

Igiri, Juliana A., Department of Agricultural Economics, Faculty of Agriculture, Forestry and Wildlife Resources Management, University of Calabar, PMB 1115 Calabar, Nigeria.

Ihejiamaizu, Victor C., Department of Agricultural Economics, Faculty of Agriculture, Forestry and Wildlife Resources Management, University of Calabar, PMB 1115 Calabar, Nigeria. 
48.72 percent of the total livestock production in the country, which indicates the place of broiler sub sector in the livestock industry. Broiler as a subsector of the agriculture sector, has become popular industry for the small holders that have great contribution to the economy of the country. The subsector was particularly important in improving the employment opportunity and annual food production in Nigeria (Aniekan, Udoro and Ediomi, 2020). A study by Ameh, Suleiman $M$ and Danwanka (2016) shows that about $14 \%$ of the Nigerian population are engaged in broiler production, mostly on subsistence and small or medium sized farms. A good number of the stock of the broiler resource in Nigeria as in most part of Africa is under commercial production for meat, raised under the intensive and semi-intensive husbandry (Emokaro and Eweka, 2016). In spite of this shift, Omolayo (2018) maintained that the output level still remains low compared to the input committed and the broiler products are grossly inadequate because the supply is lower than the demand. Hence, there is need for increase in the production of broiler. The broiler industry falls short of its aim of self-sufficiency in animal protein consumption in the country that is put at $5 \mathrm{gm} /$ caput per day which is a far cry from the recommended level of $35 \mathrm{gm} /$ caput per day (Food and Agriculture Organization (FAO, 2019). Appreciable increase in broiler production is yet to be attained in Nigeria due largely to the high cost of production. For example, broiler farmers are faced with the problem of extremely high cost of day-old chicks, drugs and other poultry inputs (Ezeano and Ohaemesi, 2020).

Broiler farmers, as all other farmers use profitability ratios to measure and evaluate their farm's ability to generate income relative to their revenue and operating cost during a particular period of time. This is because it is a well-known fact that the overall essence of venturing in broiler business is to make profit. This is in line with the assertion of Ettah, Ettah and Ukwuaba (2018) that the growth of a business can only be successfully appraised by studying the profitability of the business. Analyzing the income remaining from the capital after subtracting all the overhead cost, will help check the business performance. Based on this, the study seeks to examine the profitability of broiler production in Cross River State, Nigeria.

\section{OBJECTIVES OF THE STUDY}

The following specific objectives:

(i) estimate the profitability of broiler production and

(ii) ascertain the constraints associated with broiler production.

The findings of the study are expected to be helpful to the broiler farmers and policy makers for taking appropriate decisions regarding further expansion of commercial broiler production. It will also provide some basic information to policy makers, production economist, extension workers.

\section{HYPOTHESES OF THE STUDY}

(i). broiler farmers do not make profit from broiler production

\section{RESEARCH METHODOLOGY The Area of study}

Cross River State, Nigeria is the study area. The state was purposively chosen for this study because of two reasons: The peculiarity of this research problem in the area and the familiarity of the researcher to the area, factors that facilitated data generation. The State is bounded by the States of Benue in the North, Ebonyi on the West, Akwa Ibom on the South west. It is bordered on the east by the Cameroon Republic and fronts the Atlantic Ocean on the South (Boundaries Commission, Newsletter, 2010).

The state lies between latitude $4^{\circ} 15$, North and $7^{\circ} 00$ North and longitude $7^{\circ} 15^{\prime}$ East and $9^{\circ} 30$ 'East (Cross River State tourism guide, 2009). According to Federal Office of Statistics (FOS, 2007) the land area of Cross River State is about 7,782 square miles or 20,156 square kilometers and the population standing at $2,888,966$ persons (NPC, 2006). Following an annual growth rate of $2.9 \%$, it is expected that the population of Cross River State will hit over 3,700,000 million people by 2021.

The mean annual rainfall is between $1,300 \mathrm{~mm}$ to $3,000 \mathrm{~mm}$, which varies from place to place across the state (Cross River State Tourism Guide, 2011). According to the tourism guide, highest temperature is recorded between February and March and does not exceed $37^{\circ} \mathrm{C}$ and the lowest between May and October and does not go below $15^{\circ} \mathrm{C}$ and also varies from place to place. The vegetation of the state parades four distinct features: Mangrove Swamp (wetland), rainforest, derived savannah and parkland (Cross River Tourism Bulletin, 2011). The type of soil found in the area is deep laterite fertile and dark clayey basalt. Hence, agriculture is the major activity of Cross Riverians with livestock production dominant.

\section{SAMPLING TECHNIQUES, SIZE AND METHOD OF DATA COLLECTION}

Multi-stage sampling technique was adopted in the selection of 180 respondents which involved three stages as follows: first stage was the purposive selection of four local government areas (L.G.A,'s) based on the preponderance of broiler production. The LGA's included Etung, Obubra, Ikom and Yakurr. Second stage was the random selection of 3 villages from each of the L.G. A's earlier selected making a total of 12 villages in the sample. The villages were Efraya, Agbokim and Etome from Etung L.G.A, Ovonum, Ofodua and Oyadama from Obubra L.G.A, Ofutop, Okuni and Akam from Ikom L.G.A and Ugep, Ekori and Nko from Yakurr L.G.A. The third stage involved the random selection of 15 respondents who are involved in broiler production from each of the earlier selected villages of the L.G. As, accordingly 180 respondents formed the sample. Primary data were used for this study. The data were obtained from structured questionnaires and personal interviews, designed based on the research objectives. Finally, relevant tables were prepared in accordance with the objectives of the study. Analytical Techniques

Data collected were analysed using descriptive statistics such as frequency, mean, ranking and percentages for objectives i and iii. Objective ii was realized using budgeting techniques tools such as net farm income (NFI), return to naira invested (RNI), gross and operating ratios (GR and $O R$ ) respectively.

Net farm income (NFI) = GR- (TFC + TVC)

Where: $\mathrm{NFI}=$ Net farm income ( $), \mathrm{GR}=$ Gross revenue (\#), TFC = Total fixed cost (\#), TVC = total variable cost 
(\#). TVC includes total cost of production like cost of day old chick, cost of feed, cost of medications, cost of labour, etc. and TFC includes total fixed cost: rental value of buildings/structures and equipment.

$\mathrm{RNI}=$ this is given as $\mathrm{TFI} / \mathrm{TC}$, where $\mathrm{RNI}=$ return to naira invested, $\mathrm{TFI}=$ total farm income and $\mathrm{TC}=$ total cost of production.

\section{INFLUENCE OF SOCIO-ECONOMIC ATTRIBUTES} OF BROILERS FARMERS

The analysis of socio-economic attributes of broiler farmers in the area is presented in Table 1 below. The
$\mathrm{GR}=$ this is given as TC/TR, where GR = Gross ratio, $T C=$ as specified above and $T R=$ total revenue

$\mathrm{OR}=$ this is given as TVC/TR, where OR = operating ratio and TVC and TR as described above respectively. It is important to note that the operating ratio measures the solvency of the business.

characteristics examined were age, sex, marital status, education, experience, household size business size and training.

Table 1 Socio-economic characteristics of poultry farmers

\begin{tabular}{|c|c|c|c|}
\hline Variable & Frequency $(\mathrm{N}-180)$ & Percentage (\%) & Mean \\
\hline \multicolumn{4}{|l|}{ Age } \\
\hline$\leq 20$ & 5 & 2.8 & $35.34(13.047)$ \\
\hline $21-40$ & 92 & 51.2 & \\
\hline $41-60$ & 55 & 30.5 & \\
\hline 61above & 28 & 15.5 & \\
\hline \multicolumn{4}{|l|}{ Sex } \\
\hline Male & 131 & 72.7 & \\
\hline Female & 49 & 27.3 & \\
\hline \multicolumn{4}{|l|}{ Marital status } \\
\hline Single & 39 & 21.7 & \\
\hline Married & 141 & 88.3 & \\
\hline \multicolumn{4}{|l|}{ Education } \\
\hline No formal educ. & 15 & 8.3 & $8.69(4.713)$ \\
\hline Primary & 45 & 25.0 & \\
\hline Secondary & 103 & 57.2 & \\
\hline Tertiary & 17 & 9.5 & \\
\hline \multicolumn{4}{|c|}{ Experience (years) } \\
\hline$\leq 5$ & 36 & 20.0 & $8.67(6.557)$ \\
\hline $6-10$ & 98 & 54.4 & \\
\hline $11-15$ & 27 & 15.0 & \\
\hline 16 above & 19 & 10.6 & \\
\hline \multicolumn{4}{|l|}{ Household size } \\
\hline$\leq 3$ & 47 & 26.1 & $6.65(6.989)$ \\
\hline $4-8$ & 82 & 45.5 & \\
\hline $9-13$ & 14 & 7.8 & \\
\hline 13 above & 8 & 4.4 & \\
\hline $151-200$ & 17 & 9.4 & \\
\hline Above 201 & 12 & 6.7 & \\
\hline \multicolumn{4}{|l|}{$\begin{array}{l}\text { Business size } \\
\text { (no. of birds) }\end{array}$} \\
\hline$\leq 50$ & 19 & 10.5 & 180 \\
\hline $51-100$ & 17 & 9.4 & \\
\hline $101-150$ & 39 & 21.6 & \\
\hline $151-200$ & 91 & 50.5 & \\
\hline Above 200 & 14 & 7.7 & \\
\hline \multicolumn{4}{|l|}{ Training } \\
\hline No & 164 & 91.1 & \\
\hline Yes & 16 & 8.9 & \\
\hline TOTAL & 180 & 100 & \\
\hline
\end{tabular}

Source: field survey 2021

Findings in Table 1 showed that $51.2 \%$ of the respondents were in the age range of 21-40 years and $2.8 \%$ in the age range of $\leq 20$ years. The mean age was 35years. This implies that most of the farmers were in their active age of maximum productivity. This result agrees with the findings of Emokaro and Eweka (2016). In their work on Comparative analysis of profitability of broiler production systems most broiler farmers were within their active years of 30's and can make meaningful contributions to broiler production. Analysis 
of gender showed that majority $(72.7 \%)$ were male. This implied that men were dominant in broiler production in the area; this may be because broiler business is rigorous and tedious, for the women folk who are always busy with other household chores.

Result on marital status showed that $88.3 \%$ of the respondents were married. This high proportion of the respondents who are married is an indication that broiler business can be used to sustain a family household. In addition, the level of educational attainment by the respondents showed that, as many as $57.2 \%$ representing the highest, had secondary education. The mean years of educational attainment were 8 years. This implied that most of the respondents attempted secondary education therefore could read and write. Ezeano and Ohaemesi (2020) documented the relevance of the literacy level of broiler farmers to efficiency. The author is of the view that education facilitates understanding of broiler production technicalities and innovations.

Findings on experience in broiler production showed $54.4 \%$ of the respondents had experience of $6-10$ years. The mean broiler production experience was 8 years. This implies that most broiler farmers have recently embraced broiler business in the area. This few years of experience could have serious implications on effective entrepreneurship of the broiler business. The result in Table 1 also showed that most farmers (45.5\%) had household size of $4-8$. The average household size was 6 persons. This implied that family expenses could have a toll on the profit of the business. This result conforms with that of Ettah, Ettah and Ukwuaba (2018), who found out that family expenses has a negative effects on profit of small holder agricultural producers. The analysis on business size showed that majority $(50,5 \%)$ of respondents had business size of 151 to 200 birds. The average farm size is 180 birds. This result implies that majority of the respondents are small holder broiler farmers. The result in Table 1 further showed that, majority $(91.1 \%)$ of the respondents never received any training on and only $8.9 \%$ received training. This result depicts low level of relevant information and understanding about broiler production activities and may likely result to inefficiency in production in the area.

\section{PROFITABILITY ANALYSIS OF BROILER PRODUCTION}

The analysis of profitability of broiler production in the area is presented in Table 2 below.

Table 2: Profitability Analysis per Production period of 8 weeks (size 200 birds, 4 cartons)

\begin{tabular}{|lll|}
\hline PARAMETERS & AMOUNT (N) & PERCENTAGE \\
\hline A. VARIABLE COST & & 18.13 \\
\hline Day old chicks & $76,000.00$ & 59.05 \\
\hline Feeds & $247,520.40$ & 4.37 \\
\hline Drugs & 18,260 & 4.10 \\
\hline Labour & 17,017 & 0.85 \\
\hline Electricity & 3,556 & 1.01 \\
\hline Saw dust & 4,200 & 0.72 \\
\hline Others & 3,000 & \\
\hline Total Variable Cost (TVC) & 9.17 \\
\hline B. FIXED COST & $\mathbf{3 6 9 , 3 5 3 . 4}$ & 2.71 \\
\hline Building & & $\mathbf{1 0 0}$ \\
\hline Equipments & 38,420 & \\
\hline Total Fixed Cost (TFC) & 11380 & \\
\hline C. TOTAL COST (TC) & $\mathbf{4 9 , 8 0 0}$ & \\
\hline D. RETURNS & $\mathbf{4 1 9 , 1 5 3 . 4}$ & \\
\hline Revenue from sale & & \\
\hline Revenue from other sales & 700,000 & \\
\hline Total Revenue (Gross income) & 4,000 & \\
\hline E. FINANCIAL ANALYSIS & 704,000 & \\
\hline Net farm income & & \\
\hline Return per naira invested & $284,846.6$ \\
\hline Gross ratio & 1.68 & \\
\hline Operating ratio & 0.59 & \\
\hline Sour: fied suvey 2021 & 0.52 & \\
\hline
\end{tabular}

Source: field survey 2021

Entries in table 2 shows that the total revenue realized from broiler production in one production season is N704,000. This results from total variable and fixed costs of N369,353.4 and N49,800 respectively, following this, the broiler business made a net income of N284,846.6, it follows therefore that the broiler farmers made profit. The return per naira invested ratio was
1.68 , this means that for every naira invested, $\mathrm{N} 1.68$ profit is made by the broiler farmer, this further indicates that the business is profitable. The gross ratio, which measures the overall financial success of the business recorded 0.59 , the rule of thumb is that a less than one ratio is preferable for any farm business and the lower the ratio the higher the profit (Aniekan, Udoro and 
Ediomi, 2020). This result is therefore plausible for the broiler business in the study area. The operating ratio is 0.52 , the rule of thumb above also applies in this ratio and hence the result shows that the business is profitable.

\section{CONSTRAINTS OF BROILER PRODUCTION}

Determination of the constraints of broiler production in the study area is presented in table 3 below.

Table 3: Constraints of Broiler Production in the Study Area

\begin{tabular}{llll}
\hline Problems & Frequency & Percentage * & Rank \\
\hline High cost of feed & 180 & 100 & 1 \\
High cost of day old chicks & 172 & 95 & 2 \\
Insufficient extension service & 156 & 86 & 3 \\
Financial constraints & 151 & 84 & 4 \\
High cost of drugs/medication & 102 & 56 & 5 \\
High mortality rate & 80 & 44 & 6 \\
Difficulty in litter management & 69 & 38 & 7 \\
Harsh weather & 22 & 12 & 8 \\
\hline
\end{tabular}

Source: field survey $2021{ }^{*}$ Multiple Responses were observed

The result shows that all the respondents (100\%) identified high cost of feed as a major constraint to broiler production, hence ranked the first in the constraints. High cost of feeds is occasioned by the ban on their importation, in the face of low production from local manufacturers of the feeds, this result is in line with the findings of Ameh, Suleiman and Danwanka (2016). They also noted that high cost of maize and sorghum, the major raw materials resulting from poor harvest of the crop, because of insurrection in the regions producing the crops is also a contributory factor to the high cost of feeds. High cost of day old chicks (95\%), recorded the second highest constraint in broiler production in the area, this is as a result of few producers of day old chick in the area, as a result of the high technology and expertise involved in it production. Insufficient extension service was ranked third with $86 \%$ of the respondent, identifying this variable as a major constraint to broiler production. This service is hardly delivered to broiler farmers as a result of governments' lackluster attitude toward agricultural development. Financial constraint $(84 \%)$ returned the $4^{\text {th }}$ position in ranking of the constraints associated with broiler production. This could be because of the difficulty of assessing loans, credit and incentives from government in the study area. Loan officers' demands conditions that cannot be easily met by these small holder farmers. Also government's incentives/grants hardly get to this category of farmers, they end up with false farmers and few medium scale ones. The fifth ranking constraint is high cost of drugs/medication; dealers on this drug/medication blame the high cost on the high exchange rate of the naira to the dollars, this has increased the mortality rate recorded in broiler production in the area.

High mortality rate $(44 \%)$ came $6^{\text {th }}$ in ranking, respondents blame it on lack of relevant training on broiler production, poor condition of production and inadequate hands, resulting from high cost of hired labour to handle the daily care of the broiler farm this result is in line with that of Ezeano and Ohaemesi (2020), who found out that the high mortality in broiler production recorded from the farmers studied to lack of training in handling the birds. Thirty-eight percent of respondents identified difficulty in litter management as a constraint in broiler production, this variable came $7^{\text {th }}$ in ranking. High cost and inadequate labour is a major reason for this problem in broiler production and has increase the mortality rate of broiler birds. Finally, harsh weather is the least ranking constraint, this is because this variable can be controlled or managed by the farmer. The dominant harsh weather that affects broiler production is cold and this can be controlled by heating the farm with either electricity or local fire/lantern.

\section{CONCLUSION AND POLICY RECOMMENDATIONS}

The socio-economic attributes of broiler farmers - age, sex, marital status, education, experience, business size and training influenced the profitability of broiler production in the area. Furthermore, the study revealed that broiler production is a profitable venture in the area. the broiler business made a net income of $31.74 \%$ of the total amount of money invested, within a production season of eight weeks. However, cost of feeds, lack of extension services, financial constraints, cost of day old chicks medication among others are the constraints affecting effective broiler production in the area. Based on the findings of this study, the following are recommended: regular extension training on broiler production should be carried out by the relevant government agencies, feeds should be subsidized and made easily available by government, production of day old chicks should be subsidized by government to cushion the effect of their high cost and livestock farmers should be encouraged to invest on the poultry subsector for it profitability.

\section{REFERENCES}

Ameh, B. O., Suleiman, M. and Danwanka, H., 2016. Economic analysis of broiler production in Lokoja Local Government of Kogi State, Nigeria. Proceedings of the conference of the National Association of Agricultural Economists held at FUT Owerri, 2016.

Aniekan, J. A., Udoro, J. U. and Ediomi, U. A., 2020. Comparative cost and return of broiler and layer birds in a risky environment: a case of Akwa Ibom Stae, Nigeria. Proceedings of Nigeria Agricultural Economist Association (NAEE), 2020. 
Boundaries Commission Newsletter 2012. A publication of national Boundaries Commission Abuja, Nigeria. 2012 pp. 4 - 8.

Cross River State Tourism Bulletin 2010. Annual publication of tourism potentials of Cross River State, Calabar, Nigeria Pp. 3-9.

Cross River Agricultural Development Project, 2012. The impact of Cross River Agricultural and Rural Development Projects in Cross River State: Quarterly Bulletin, 13, 13-19.

Emokaro, C. O. and Eweka, K. I., 2016. Comparative analysis of profitability of broiler production systems in Urban areas of Edo State, Nigeria. Journal of applied science and environmental management. 19 (4): 627

Ettah, O., I. and Kuye O. O., 2017. Analysis and Determinants of Profit Efficiency of Cassava Farmers in Cross River State, Nigeria, International Journal of Environment Agriculture and Biotechnology. 2 (1) 225-229.

Ettah, O. I, Ettah, Goddy I., Ukwuaba, I. C., 2018. Analysis of Profitability in Maize Production in Obubra Local Government Area of Cross River State, Nigeria. International Journal of Interdisciplinary Research and Innovations. 6 (1), January 2018- March.
Ezeano, C. I and Ohaemesi, C. F., 2020. Comparative analysis of broiler and turkey production in Anambra State, Nigeria. International journal of science and research IJRS. 9 (2).

Food and Agricultural Organisation, 2019. Quarterly Agricultural bulletin, 2019 (statistics) publication of Food and Agricultural Organization F. A. O., 2019 Pp.11-115.

Ike, P. C. and Ugwumba, C. O. A., 2011. Profitability of small-scale broiler production in Onitsha North Local Government Area of Anambra State, Nigeria. International journal of poultry science. 10 (2). 106-109.

Mgbakor, M. N. and Nzeadachie, C., 2013. Economic analysis of broiler production. A case of Orumba South Local Government Area of Anambra State, Nigeria. American-Eurasian journal of Agronomy. 6 (2). 25-31.

National population commission, 2006. Census enumeration survey N. P. C. Abuja, Nigeria. 2, 6-8. Nigeria.

National Bureau of Statistrics NBS., 2020. Livestock Production Report in Nigeria 2020. NBS annual report, Abuja.

Omolayo, J. O., 2018. Economic analysis of broiler production in Lagos State Poultry Estate, Nigeria. Journal of Investment Management. $7(1)$. 